\title{
Problems Of Msmes And Entrepreneurs In Kadapa District
}

\author{
*K.Suneetha and ** T.Sankaraiah \\ *Assistant professor Department of Econometrics S.V.University Tirupati \\ ** Associate professor Department of Econometrics S.V.University Tirupati
}

\begin{abstract}
Women constitute 50 per cent of the total population of India. Of late, they are actively engaging in several activities apart from employment. Women are involving and entering into business and establishing different types of industries. women started establishing industries and collaborating self and economic development and coming out with flying colours. Out of the total sample of 156 enterprises, 103 enterprises (66.2\%) are facing the financial problem and among them and 62.8 per cent are from Micro enterprises. Moreover, 23.0 per cent found as meager assistance from government agencies. There are 64.6 per cent (37 of 58) enterprises from Kadapa division, 73.1 per cent (38 of 52) enterprises from Jammulamadugu division and 65.0 per cent (30 of 46) enterprises from Rajampet division facing the financial problem. irrespective of these divisions 66.2 per cent of entrepreneurs/ enterprises are facing the same level of financial problems. There are 55 enterprises (69.3\%) located in Rural areas, 25 enterprises (70.6 \%) of 36 are located in Semi-Urban areas and 23 enterprises(56.4\%) of 41 are located in Urban areas facing the financial problems.
\end{abstract}

\section{Introduction}

Women constitute 50 per cent of the total population of India. In spite of it, women are still lagging behind men in several aspects. Over the years, the literacy rate of women and employment opportunities are being increased by leaps and bounds. Moreover, of late, they are actively engaging in several activities apart from employment. Women are involving and entering into business and establishing different types of industries. The Government of Indian and Andhra Pradesh have been encouraging women to take up industrial establishments. Several financial corporations are funding for establishment of industries. Hence, women started establishing industries and collaborating self and economic development and coming out with flying colours. The policy makers, and administrators in India have for long recognized, the important role that Micro, Small and Medium Enterprises play in the national economy, therefore the Central and State Governments have taken over the years active steps to promote and foster their growth. But these measures have not been particularly effective. Today, these enterprises continue to suffer from innumerable problems which hinder their performance and growth. Many of the problems of finance, marketing, production, distribution and infrastructure still continue to afflict the MSME sector. While some of them are more or less common to a wide range of small enterprises all over the country, others have particular relevance to groups of small enterprises situated in rural and backward areas. In this paper the problems faced by the entrepreneurs/ enterprises in Kadapa district of Andhra Pradesh are detailed.

Women Entrepreneurs may be defined as the women or a group of women who initiate, organize and operate a business enterprise. The Government of India has defined women entrepreneurs as an enterprise owned and controlled by women having a minimum financial interest of 51 per cent of the capital and giving at least 51 per cent of the employment generated in the enterprise to women. Women entrepreneurs engaged in business due to push and pull factors which encourage women to stand on their on legs. Under the influence of these factors the women entrepreneurs choose a profession as a challenge and as an urge to do something new. Such a situation is described as pull factors. While in push factors women engaged in business activities due to family compulsion and the responsibility is thrust upon them.

\section{Review Of Literature}

Meenu Goyal and Jai Parkash(2011) opined that the educated Indian women have to go a long way to achieve equal rights and position because traditions are deep rooted in Indian society where the sociological set up has been a male dominated one. The present paper endeavors to study the concept of women entrepreneurReasons women become entrepreneurs -Reasons for slow progress of women entrepreneurs in India suggestions for the growth of women entrepreneurs-Schemes for promotion \& development of women entrepreneurship in India-Case study of a women entrepreneur of Ludhiana.

Vargheese Antony Jesurajan.S and Dr. M. Edwin Gnanadhas (2011) in their study revealed that husbands/fathers were the main motivators for taking up entrepreneurship. So motivation of husbands/fathers/family members would certainly prove to be fruitful. Once they get convinced about 
significance of women entrepreneurship then their attitude will change, their roles and expectations will change and they will provide moral support, necessary guidance and help as needed.

Deepti Pachauri (2012)attempt study that based on the emergence of women entrepreneurship making significant impact in all segments of economy and the problems faced by them in setting up and running their enterprise. The study was conducted in various training centres of KVIC, MSME to collect the data and no. of women entrepreneur trainees'. The study was based on secondary data collected from various training institutes, SSI office and financial banks which provide financial assistance. Women entrepreneurs are having innovative thinking and foresightedness yet proper planning and execution is required at all levels. A majority of women entrepreneurs are from middle class families have low technical education but desire to become entrepreneurs. The literacy and educational status of women improved considerably during the past few decades. At this juncture effective steps are needed to provide entrepreneurial orientation and skill awareness to women.

Jyothi Bahl(2012) expressed that the entrepreneurship has gained greater significance at global level under changing economic scenario. After independence, several entrepreneurship development programs have been started to develop the skill, knowledge, and competence among the entrepreneur. In spite of various entrepreneurship development programmes launched by the Govt. and non-government agencies, the entrepreneurs are encountering a number of problems for establishing economically viable small- scale units. Women contribute significantly to the running of family businesses mostly in the form of unpaid effort and skills. Rural entrepreneurship is the answer to removal of rural poverty in India. The problem is that most of the rural youth do not think of entrepreneurship as the career option. Therefore, the rural youth need to be motivated to take up entrepreneurship as a career, with training and sustaining support systems providing all necessary assistance.

Palaniappan.G, C. S. Ramani Gopal and A. Mani(2012) are analyzed that the women have been successful in breaking their confinement within the limits of their homes by entering into varied kinds of professionals and services women entrepreneurs have proved to be on par with their men counterparts in business acumen and are emerging as smart and dynamic entrepreneurs. Women owned businesses are highly increasing in the economies of almost all countries. The hidden entrepreneurial potentials of women have gradually been changing with the growing sensitivity to the role and economic status in the society. Even though the government organizes women by various associations, they are not ready to undertake the business. Thus, the study aims at undertaking the entrepreneurial development among women highlights their motivational forces and relationship between socio-economic background of women entrepreneurs, motivational factors and their existing entrepreneurial traits.

Shabana A. Memon (2012) says that the entrepreneurship is a key element of growth and development prospects for all countries and it is most relevant to transition countries. Just a policy of wage employment will not solve the grave unemployment problem. The only solution is promotion and development of Entrepreneurship, as entrepreneurship aims at making an individual a job provider and not a job seeker. Entrepreneurship has been a male-dominated phenomenon from the very early age but time has changed the situation and brought women as today's most memorable and inspirational entrepreneurs. Around 50 women entrepreneurs in Kolhapur city were surveyed through a questionnaire and an attempt is made in this paper to highlight major issues of women entrepreneurs, identify potentialities of enterprising women who are successful and thereby provide role models for potential women entrepreneurs particularly for young women entering the labor market for the first time.

Siva (2012) studied that the small scale sector produces a wide range of products, from simple consumer goods to highly precision and sophisticated end-products. As ancillaries, they produce a variety of parts and components required by the large enterprises. Entrepreneurs can be developed through the practical application of entrepreneurship skills. As the study of this topic, would pictures the problems faced by Entrepreneurs of small scale industries. A Sample design adopted was purposive and convenience. The sample size selected for the study was 50. To analyze the data is by using Descriptive analysis, using frequency, tables and graphs were attempted. Secondly, Chi-Square test \& T Test was used, to test for differences.

Soni Kumara(2012) analyzed that the inspire of forming 50 per cent of the total population of the world women do not own even 1 per cent of the world's property. Their role and contribution in industrialization has remained unaccounted and unassisted. The lot and the position of women the world over has remained neglected. Their share in business and trade is very low. Women have an important role to play in synthesizing social progress with economic growth of developing countries. The specific role of women in the economic effort has not yet been clearly defined but the need for "integration of women into development" is being particularly felt by women themselves. With the increase in the number of women getting educated, there is considerable awareness among women to be self-employed and gradually the role of women is changing in the society.

Venkatesh Babu(2012) states that the entrepreneur is a person who is responsible for setting up of a business or an enterprise. Entrepreneur creates new business, generating jobs for themselves those they employ. 
Entrepreneurship is vast field; it is difficult to conduct research on whole field. In the present study an attempt has been made to know the challenges and prospectus for Women Entrepreneurship in India in general and in specific in Davangere city. To conduct study three successful women entrepreneurs were selected irrespective of field. Women are selected from Shaviyagi industries field, DTP field and Hotel field. Information has been collected from the entire three entrepreneurs and analyzed the case on the basis of information provided by them, problems faced by them and prospectus or remedies taken to overcome the problems and their entrepreneurial successful mantra also discussed in this paper.

Alit Sen Guptha(2012) says that the paper tries to focus on the women entrepreneur development prospects. The survey and the study brought to light the capacity of the women who came forward with the ability to use the unutilized resource. The sample survey of the various districts clarifies that though immense prospect prevail and the zeal of the women to start something new has been crushed down with the ongoing problem prevailing in the area. The objective of the study was to explore the hidden prospect of women entrepreneurship and to find technique to up lift anxiety for leadership in women while tracking to reach the expected objective the methodology so adopted was a sample convenient method for various districts. The problems are many but to bring out the entire population out of the grip of prejudice, mentally the women should get themselves prepared to change with the changing environment.

Renu Chaudhary (2013) analyzed that the woman constitutes the family, which leads to society and Nation. Social and economic development of women is necessary for overall economic development of any society or a country. Entrepreneurship is the state of mind which every woman has in her but has not been capitalized in India in way in which it should be. Due to change in environment, now people are more comfortable to accept leading role of women in our society, though there are some exceptions. Our increasing dependency on service sector has created many entrepreneurial opportunities especially for women where they can excel their skills with maintaining balance in their life. Propose of this study is intended to find out various problems being faced by women entrepreneurs in India.

Vijay Kumumbhar(2013) analyzed that the aim of this study is to discuss the issues regarding women entrepreneurship in rural India. This paper is mostly based on secondary data and some observations for the identification of these issues the author has reviewed different research articles and reports. Findings of this study reveal that absence of definite agenda of life, absence of balance between family and career obligations of women, poor degree of financial freedom for women, absence of direct ownership of the property etc.

\section{Methodology}

The present study avails both primary and secondary data to study extensively the women entrepreneurs and their development in Kadapa district. Purposive sampling method has been adopted for the present study and according to the information provided by the District Industries Centre (DIC) Kadapa district. The sample size of the study comprised 156 which consist of 50 percent of total 312 industrial units.

\section{PROBLEMS OF MSMES AND ENTREPRENEURS}

Women entrepreneurs of MSMEs face generally problems such as financial, raw material, Sales / Marketing, Labour/Employee, Infrastructural and Operational Problem. The present paper attempts to ascertain the financial problems.

\section{Financial Problems}

Generally, most entrepreneurs face the problem of finance at the time of making the initial investment as well as during the course of management of the enterprise (V.P.Kharbanda, 2001). Poor financial situations and low levels of R\&D are the reasons for the inability of MSMEs to identify their needs. S.N.Patnaik (1991) in his study found that almost all enterprises faced difficulties in raising term loans and working capital. R.P.Sinha (1991) in a study of 100 small enterprises in Patna city of Bihar State found that 85 per cent enterprises faced the problem of finance. Finance is not easy to come by as the entrepreneurs have to depend on more than one source and pay heavy investment charges and pass through many an ordeal and subsequent delay. Similarly enterprises which are ancillary to other large enterprises do not receive timely payments from the mother enterprises for their supply.

\section{Enterprise-wise Financial Problems}

The financial problems of entrepreneurs/enterprises in the study area have been resented in the Table 1. 
Table 1

Enterprise-wise Financial Problem

\begin{tabular}{|c|c|c|c|c|}
\hline \multirow[t]{2}{*}{ Response of Financial Problem } & \multicolumn{3}{|c|}{ Enterprise } & \multirow[t]{2}{*}{ Total } \\
\hline & Micro & Small & Medium & \\
\hline Yes & $62.8 \%$ & $76.8 \%$ & $50 \%$ & $66.2 \%$ \\
\hline No & $37.2 \%$ & $23.2 \%$ & $50 \%$ & $33.8 \%$ \\
\hline \multirow[t]{2}{*}{ Total } & 109 & 43 & 4 & 156 \\
\hline & $100.0 \%$ & $100.0 \%$ & $100.0 \%$ & $100.0 \%$ \\
\hline
\end{tabular}

Source: Field Survey

Out of the sample 156 enterprises, 103 enterprises $(66.2 \%)$ are facing the financial problem and 53 enterprises $(33.8 \%$ ) are not facing the financial problem. The financial problems arise for well establishment of infrastructure, sophisticated technology and good facilities in the enterprises. Of them, 62.8 per cent (68 out of 109) are from Micro enterprises, 76.8 per cent (33 out of 43) are from Small enterprises and 42.9 per cent ( 2 out of 4) are from Medium enterprises have the financial problem. Table 2 .

The different financial problems faced by the enterprises in the study area have been presented in the

Table 2

Financial Problems of Enterprises

\begin{tabular}{|c|c|c|c|c|c|}
\hline & & & & (Mu & Respo \\
\hline \multirow{2}{*}{ Sl. No. } & \multirow{2}{*}{ Problems } & \multicolumn{3}{|c|}{ Enterprise } & \multirow{2}{*}{ Total } \\
\hline & & Micro & Small & Medium & \\
\hline \multirow{2}{*}{$\begin{array}{l}1 \\
2\end{array}$} & \multirow{2}{*}{ Shortage of Fixed Capital } & 28 & 17 & 1 & 46 \\
\hline & & $13.50 \%$ & $20.70 \%$ & $14.30 \%$ & $15.50 \%$ \\
\hline \multirow{2}{*}{3} & \multirow{2}{*}{ Shortage of Working Capital } & 69 & 30 & 1 & 100 \\
\hline & & $33.3 \%$ & $36.6 \%$ & $14.3 \%$ & $33.8 \%$ \\
\hline \multirow{2}{*}{4} & \multirow{2}{*}{ High Rate of Interest } & 33 & 19 & 0 & 52 \\
\hline & & $15.9 \%$ & $23.2 \%$ & $0.0 \%$ & $17.6 \%$ \\
\hline \multirow{2}{*}{5} & \multirow{2}{*}{ Meagre Assistance from Govt. Agencies } & 50 & 17 & 1 & 68 \\
\hline & & $24.2 \%$ & $20.7 \%$ & $14.3 \%$ & $23.0 \%$ \\
\hline \multirow{2}{*}{6} & \multirow{2}{*}{ Others } & 0 & 5 & 0 & 5 \\
\hline & & $0.0 \%$ & $6.1 \%$ & $0.0 \%$ & $1.7 \%$ \\
\hline
\end{tabular}

Source: Researcher Compilation

Out of the sample 156 enterprises, 15.50 per cent faced shortage of fixed capital, 33.80 per cent faced shortage of working capital, 17.60 per cent faced high rate of interest, 23.0 per cent found as meager assistance from government agencies and 1.7 per cent faced the other financial problems. These figures reveal that the shortage of working capital has the major problem were facing the sample entrepreneurs/enterprises.

\section{Division-wise Financial Problems}

The financial problems faced by the sample entrepreneurs/enterprises in all the 3 divisions have been furnished in the table 3 .

Table 3

Division-wise Financial Problems

\begin{tabular}{|c|c|c|c|c|}
\hline Chi-square value & p-value & \multicolumn{2}{|c|}{ Financial Problems } & \multirow{2}{*}{ Total } \\
\hline 1.332 & 0.514 & Yes & No & \\
\hline \multirow{6}{*}{ Division } & \multirow{2}{*}{ Kadapa } & 37 & 21 & 58 \\
\hline & & $64.6 \%$ & $35.4 \%$ & $100.0 \%$ \\
\hline & \multirow{2}{*}{ Jammulamadugu } & 38 & 14 & 52 \\
\hline & & $73.1 \%$ & $26.9 \%$ & $100.0 \%$ \\
\hline & \multirow{2}{*}{ Rajampet } & 30 & 16 & 46 \\
\hline & & $65.0 \%$ & $35.0 \%$ & $100.0 \%$ \\
\hline \multirow{2}{*}{\multicolumn{2}{|c|}{ Total }} & 103 & 53 & 156 \\
\hline & & $66.2 \%$ & $33.8 \%$ & $100.0 \%$ \\
\hline
\end{tabular}


Source: Researcher Compilation

. There are 64.6 per cent (37 of 58) enterprises from Kadapa division, 73.1 per cent (38 of 52) enterprises from Jammulamadugu division and 65.0 per cent (30 of 46) enterprises from Rajampet division facing the financial problem. To study the association between these divisions Kadapa, Jammulamadugu and Rajampet and level of financial problems faced by the entrepreneurs /enterprises, the results shown that there is no significant association between them (Chi-square value $=1.332 ; \mathrm{p}$-value $=0.514)$. It means, irrespective of these divisions 66.2 per cent of entrepreneurs/ enterprises are facing the same level of financial problems.

\section{Location-wise Financial Problems}

The Financial problems faced by the sample entrepreneurs/enterprises in all the three locations have been presented in the Table 4 .

Table 4

Location-wise Financial Problems

\begin{tabular}{|c|c|c|c|c|}
\hline \multirow{2}{*}{ Chi-square value } & \multirow{2}{*}{ p-value } & \multicolumn{2}{|c|}{ Financial Problems } & \multirow{2}{*}{ Total } \\
\hline \multirow{4}{4.585}{} & $\mathbf{0 . 1 0 1}$ & Yes & No & \\
\hline \multirow{3}{*}{ Location } & \multirow{2}{*}{ Rural } & 55 & 24 & 79 \\
\cline { 2 - 5 } & & $69.3 \%$ & $30.7 \%$ & $100.0 \%$ \\
\cline { 2 - 5 } & \multirow{2}{*}{ Semi Urban } & 25 & 11 & 36 \\
\cline { 2 - 5 } & \multirow{2}{*}{ Urban } & $70.6 \%$ & $29.4 \%$ & $100.0 \%$ \\
\cline { 3 - 5 } & & 23 & 18 & 41 \\
\hline \multirow{2}{*}{ Total } & $56.4 \%$ & $43.6 \%$ & $100.0 \%$ \\
\cline { 3 - 5 } & & 103 & 53 & 156 \\
\hline \multirow{2}{*}{} & & $66.2 \%$ & $33.8 \%$ & $100.0 \%$ \\
\hline
\end{tabular}

Source : Researcher Compilation

The table portrays that there are 55 enterprises $(69.3 \%)$ located in Rural areas, 25 enterprises (70.6\%) of 36 are located in Semi-Urban areas and 23 enterprises (56.4\%) of 41 are located in Urban areas are the financial problems. Further Chi-Square test reveals that, there is no significant impact between the location of the enterprises and level of financial problems faced by the entrepreneurs /enterprises (Chi-square value $=4.585$; $\mathrm{p}$-value $=0.101$ ), it means irrespective of these locations, 66.2 per cent of entrepreneurs/enterprises are facing the same level of financial problems.

\section{Group-wise Financial Problems}

The financial problems faced by the sample entrepreneurs/enterprises in various category of the enterprise are presented in the Table 5.

Table 5

Enterprise Group-wise Financial Problems

\begin{tabular}{|c|c|c|c|c|}
\hline Chi-square value & p-value & \multicolumn{2}{|c|}{ Financial Problems } & \multirow{2}{*}{ Total } \\
\hline 6.282 & 0.280 & Yes & No & \\
\hline \multirow{12}{*}{$\begin{array}{l}\text { Enterprise } \\
\text { Group }\end{array}$} & \multirow{2}{*}{$\begin{array}{l}\text { Agro, Forest and Animal } \\
\text { based }\end{array}$} & 18 & 5 & 23 \\
\hline & & $79.5 \%$ & $20.5 \%$ & $100.0 \%$ \\
\hline & \multirow{2}{*}{ Textiles based } & 10 & 7 & 17 \\
\hline & & $59.4 \%$ & $40.6 \%$ & $100.0 \%$ \\
\hline & \multirow{2}{*}{ Mineral based } & 16 & 9 & 25 \\
\hline & & $62.5 \%$ & $37.5 \%$ & $100.0 \%$ \\
\hline & \multirow{2}{*}{ Engineering based } & 12 & 9 & 21 \\
\hline & & $56.4 \%$ & $43.6 \%$ & $100.0 \%$ \\
\hline & \multirow{2}{*}{ Chemical based } & 12 & 6 & 18 \\
\hline & & $56.4 \%$ & $33.3 \%$ & $100.0 \%$ \\
\hline & \multirow{2}{*}{ Others } & 35 & 17 & 52 \\
\hline & & $68.0 \%$ & $32.0 \%$ & $100.0 \%$ \\
\hline \multirow{2}{*}{\multicolumn{2}{|c|}{ Total }} & 103 & 53 & 156 \\
\hline & & $66.2 \%$ & $33.8 \%$ & $100.0 \%$ \\
\hline
\end{tabular}

Source: Researcher Compilation 
The table presents that 18 of 33 Agro, Forest and Animal based (79.5\%), 10 of 17 Textile based (59.4 $\%), 16$ of 25 Mineral based(62.5\%), 12 of 21 Engineering based(56.4\%), 12 of 18 Chemical based (66.7\%) and 35 of 52 enterprises of other nature of the category $(68.0 \%)$ are facing the financial problems. Additionally, Chi-Square test reveals that, there is no significant association between the category of the enterprises and level of financial problems faced (Chi-square value $=6.282$; $p$-value $=0.280$ ). This shows that irrespective of these categories of the enterprises, 66.2 per cent of entrepreneurs/enterprises are facing the same level of financial problems.

\section{Organisation-wise Financial Problems} the Table 6.

The organization-wise sample entrepreneurs/enterprises facing the financial problems are presented in

Table 6

Organisation-wise Financial Problems

\begin{tabular}{|c|c|c|c|c|}
\hline Chi-square value & p-value & \multicolumn{2}{|c|}{ Financial Problems } & \multirow{2}{*}{ Total } \\
\hline 2.605 & 0.272 & Yes & No & \\
\hline \multirow{6}{*}{ Form of Organization } & \multirow{2}{*}{ Sole Proprietorship } & 62 & 28 & 90 \\
\hline & & $69.4 \%$ & $30.6 \%$ & $100.0 \%$ \\
\hline & \multirow{2}{*}{ Partnership } & 28 & 15 & 43 \\
\hline & & $64.6 \%$ & $35.4 \%$ & $100.0 \%$ \\
\hline & \multirow{2}{*}{ Private Ltd, Company } & 13 & 10 & 23 \\
\hline & & $56.8 \%$ & $43.2 \%$ & $100.0 \%$ \\
\hline & \multirow{2}{*}{ Total } & 103 & 53 & 156 \\
\hline & & $66.2 \%$ & $33.8 \%$ & $100.0 \%$ \\
\hline
\end{tabular}

Source: Researcher Compilation.

The table shows that 69.4 per cent (62 of 90) sole proprietary enterprises, 64.6 per cent (28 of 43) partnership firms and 56.8 per cent (13 of 23) private companies are facing the financial problems. From the Chi-Square test it observed that, there is no significant association between the form of organization maintained by entrepreneurs and level of financial problems faced by the entrepreneurs /enterprises. Irrespective organisation, 66.2 per cent of entrepreneurs/enterprises are facing the same level of financial problems.

\section{Nature of Activity -wise Financial Problems} activity wise.

Table 7 reveals that financial problems faced by the sample entrepreneurs/ enterprises in the Nature of

Table 7

Nature of Enterprise Activity-wise Financial Problems

\begin{tabular}{|c|c|c|c|c|}
\hline Chi-square value & p-value & \multicolumn{2}{|c|}{ Financial Problems } & \multirow{2}{*}{ Total } \\
\hline 1.728 & 0.786 & Yes & No & \\
\hline \multirow{10}{*}{$\begin{array}{c}\text { Nature of } \\
\text { Activity }\end{array}$} & \multirow{2}{*}{ Manufacturing } & 33 & 17 & 50 \\
\hline & & $66.0 \%$ & $34.0 \%$ & $100.0 \%$ \\
\hline & \multirow{2}{*}{ Assembling } & 15 & 7 & 22 \\
\hline & & $66.7 \%$ & $33.3 \%$ & $100.0 \%$ \\
\hline & \multirow{2}{*}{ Processing } & 18 & 10 & 28 \\
\hline & & $64.8 \%$ & $35.2 \%$ & $100.0 \%$ \\
\hline & \multirow{2}{*}{ Repairing \& maintenance } & 8 & 7 & 15 \\
\hline & & $57.1 \%$ & $42.9 \%$ & $100.0 \%$ \\
\hline & \multirow{2}{*}{ Services } & 29 & 12 & 41 \\
\hline & & $70.5 \%$ & $29.5 \%$ & $100.0 \%$ \\
\hline & \multirow{2}{*}{ Total } & 103 & 53 & 156 \\
\hline & & $66.2 \%$ & $33.8 \%$ & $100.0 \%$ \\
\hline
\end{tabular}

Source: Researcher Compilation

The table shows that 33 of 50 manufacturing enterprises( $66.0 \%), 15$ of 22 assembling enterprises(66.7 $\%), 18$ of 28 processing enterprises(64.8\%), 8 of 15 repairing and maintenance enterprises $(57.1 \%)$ and 29 of 41 service enterprises $(70.5 \%)$ are facing the financial problems. Further, Chi-Square test reveals that there is no significant influence between the nature of the enterprise activities and level of financial problems faced by the 
entrepreneurs / enterprises and this means 66.2 per cent of entrepreneurs / enterprises from the nature of the enterprises are facing the same level of financial problems.

\section{Conclusion}

Out of the total sample of 156 enterprises, 103 enterprises (66.2\%) are facing the financial problem and among them and 62.8 per cent are from Micro enterprises. Moreover, 23.0 per cent found as meager assistance from government agencies. The shortage of working capital has the major problem were facing the sample entrepreneurs/enterprises. There are 64.6 per cent (37 of 58) enterprises from Kadapa division, 73.1 per cent (38 of 52) enterprises from Jammulamadugu division and 65.0 per cent (30 of 46) enterprises from Rajampet division facing the financial problem. There are 55 enterprises $(69.3 \%)$ located in Rural areas, 25 enterprises (70.6\%) of 36 are located in Semi-Urban areas and 23 enterprises $(56.4 \%)$ of 41 are located in Urban areas are the financial problems. 18 of 33 Agro, Forest and Animal based (79.5\%), 10 of 17 Textile based (59.4\%), 16 of 25 Mineral based(62.5\%), 12 of 21 Engineering based(56.4\%), 12 of 18 Chemical based $(66.7 \%)$ and 35 of 52 enterprises of other nature of the category $(68.0 \%)$ are facing the financial problems. Similarly 69.4 per cent (62 of 90) Sole Proprietary enterprises, 64.6 per cent (28 of 43) Partnership firms and 56.8 per cent (13 of 23) Private Ltd. Companies are facing the financial problems. 33 of 50 Manufacturing enterprises(66.0\%), 15 of 22 Assembling enterprises(66.7\%), 18 of 28 Processing enterprises(64.8\%), 8 of 15 Repairing and Maintenance enterprises (57.1\%) and 29 of 41 service enterprises $(70.5 \%)$ are facing the financial problems. It is suggested that financial problems are solved to improve entrepreneurship development of women.

\section{References}

[1]. V. P. Kharbanda' Facilitating innovation in Indian small and medium enterprises - The role of clusters, Current Science, Vol.80, No.3, 10 Feb. 2001, p.345.

[2]. S.N.Patnaik, Development Strategy for Small Industries, In: R.S. Jalal, Industrial Entrepreneurship in Small-Scale Industries, Anmol Publications (Ed), 1991, p.179.

[3]. R.P.Sinha, Some Problems of Small-Scale Industries, Patna, 1985, p.70, In: M.A. Hasanth, Role of Commercial Banks, Classic Publishing House, New Delhi, 1991, p. 10.)

[4]. Meenu Goyal and Jai Parkash, Women Entrepreneurship in India, Problems and Prospects, ZENITH International Journal of Multidisciplinary Research, 2011.

[5]. S. Vargheese Antony Jesurajan and Dr. M. Edwin Gnanadhas, Study on the Factors Motivating Women to become Entrepreneurs in Tirunelveli District, Asian Journal of Business and Economics, 2011.

[6]. Deepti Pachauri, Enhancing Women Entrepreneurship in Different Small Scale Industrial Sectors of Agra, ACADEMICIA, March, 2012.

[7]. Jyoti Bahl, Status of Women Entrepreneurship in Rural India, Asian Journal of Multidimensional Research, July 2012.

[8]. Palaniappan.G, C.S. Ramani Gopal and A. Mani, A Study on Problem and Prospects of Women Entrepreneurs with special reference to Erode District, International Journal of Physical and Social Sciences, March 2012.

[9]. Shabana.A.Memon, A Study of Women Entrepreneurship Development in Kolhapur City, ZENITH International Journal of Business Economics \& Management Research, May 2012

[10]. Siva.S, A Study on Problems Faced by Entrepreneurs of Small Scale Industries, Asian Journal of Research in Social Science \& Humanities, April 2012.

[11]. Soni kumara, Challenges and Opportunities for Women Entrepreneurship in India under Globalization, IOSR Journal of Business and Management, 2012.

[12]. Venkatesh Babu, Challenges and Prospectus of Successful Women Entrepreneurs - A Case Study in Davangere City, International Journal of Research in Commerce, Economics and Management, 2012.

[13]. Vijay Kumbhar, Some Critical Issues of Women Entrepreneurship in Rural India, European Academic Research, Vol-I, Issue-2, May, 2013.

[14]. Renu Chaudhary, Problems Faced by Women Entrepreneurs in India, International Journal of Management and Science, Vol. 3, Issue-1, 2013.

[15]. Alit Sen Gupta, Women Entrepreneurship: Problems and Prospects in B.T.A.D, The Echo A Journal of Humanities \& Social Sciences, January, 2013. 